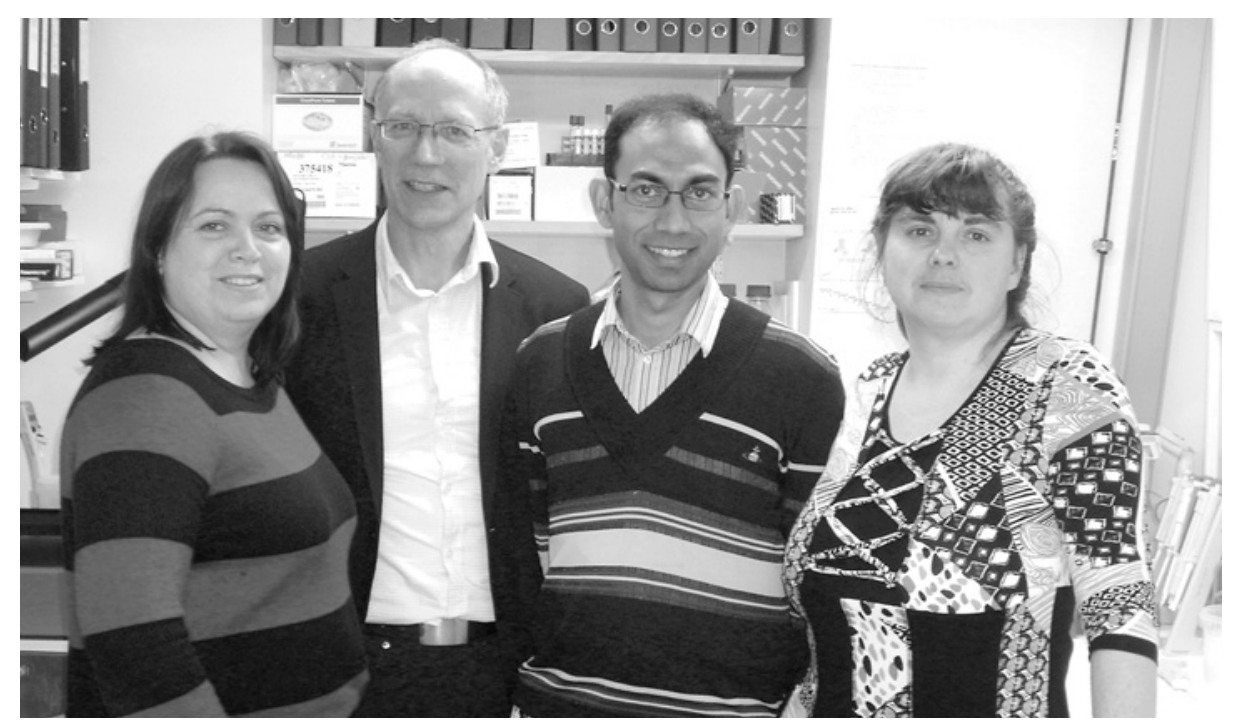

Fra venstre Mette Haugen, Christian Vedeler, Debarata Panja og Manja Schubert. En av forfatterne, Clive Bramham, var ikke til stede da bildet ble tatt. Foto: Privat

\section{Antistoffer ved paraneoplasi påvirker nevroner i lillehjernen}

Et antistoff hos pasienter med paraneoplastisk cerebellar degenerering påvirker kalsiumbalansen i purkinjeceller i cerebellum. Dette viser en ny norsk studie.

Paraneoplastiske nevrologiske sykdommer, ofte omtalt som nevrologiske fjerneffekter av kreft, er sjeldne og opptrer i under $1 \%$ av alle kreftformer. Mange av pasientene får nevrologiske symptomer mens kreften ennå ikke er erkjent. I slike tilfeller kan påvisning av en paraneoplastisk nevrologisk sykdom føre til at kreften oppdages på et tidlig stadium. Ved paraneoplastisk cerebellar degenerering har pasientene oftest underliggende ovarie- eller mammacancer. Det paraneoplastiske antistoffet som er assosiert med denne sykdommen, kalles Yo-antistoff.

I en nylig publisert studie har en forskergruppe fra Bergen vist at Yo-antistoffer kan binde seg til kalsiumregulerende proteiner (CDR2/CDR2L) i purkinjeceller, som er en type nevroner i cerebellum (1). Antistoffer fra pasienter med paraneoplastisk cerebellar degenerering ble tilsatt i cellekultur laget av cerebellum fra rotter. Yo-antistoffer, både fra pasienter og fra kanin, bandt seg til slike proteiner i purkinjecellene, mens serum fra pasienter uten slike antistoffer, renset IgG og normalt kaninserum ikke gjorde det.

- Det er tidligere vist at ulike antistoffer som binder antigener på cellemembranen kan være årsak til sykdom, og denne studien viser at også antistoffer mot intracellulære proteiner kan være patogene, sier Christian Vedeler, som er studiens sisteforfatter og professor ved Universitetet i Bergen.

- Pasienter med paraneoplastisk cere- bellar degenerering responderer dessverre dårlig på immunterapi. Det er mulig at tidlig behandling med reduksjon av CDR2/ CDR2L-antistoff og regulering av kalsiummetabolismen kan begrense tapet av purkinjeceller, det som er årsak til ataksi, tremor, dysartri og andre cerebellare utfall hos disse pasientene, sier Vedeler.

\section{Paraneoplasiforskning}

Forskningsgruppen på paraneoplastiske sykdommer i Bergen består av cellebiologer, molekylærbiologer, leger, ingeniører og studenter ved Det medisinsk-odontologiske fakultet, Universitetet i Bergen og Nevrologisk avdeling, Haukeland universitetssykehus. Forskergruppen arbeider med å identifisere hvordan CDR2/CDR2L-antistoffene kommer inn i nevronene, hvilke intracellulære strukturer som er affisert, og hvordan man kan begrense nevrontap ved paraneoplastisk sykdom.

\section{Studien ble presentert på den internasjonale} nevroimmunologikongressen ISNI i Mainz i november 2014

\section{Lise Mørkved Helsingen}

Tidsskriftet

\section{Litteratur}

1. Schubert M. Panja D, Haugen M et al. Paraneoplastic CDR2 and CDR2L antibodies affect Purkinje cell calcium homeostasis. Acta Neuropathol 2014; 128: $835-52$
Ordforklaringer

Paraneoplastisk nevrologisk sykdom: Opptrer som følge av kreft i kroppen, uten at det er tegn til metastaser til nervesystemet. Forårsakes av en autoimmun reaksjon mot kreftceller som uttrykker antigener som likner eller er identiske med antigener som finnes i nervesystemet, såkalte nevroonkogener.

Paraneoplastisk antistoff: Brukes i diagnostikk av paraneoplastisk nevrologisk sykdom. Et av disse antistoffene kalles Yo-antistoff og er rettet mot intracellulære proteiner som er relatert til cerebellar degenerering, på engelsk «cerebellar degeneration-related protein» (CDR2/CDR2L).

Purkinjeceller: Purkinjeceller er en type nevroner i cerebellum som har betydning for kontroll og koordinering av motorikk, muskeltonus og balanse samt kognitive funksjoner innenfor motorisk læring
Artikkelen ble publisert i Acta Neuropathologica, et av de høyest rangerte tidsskriftene innen patologi og klinisk nevrologi, i desember 2014 